\title{
Acute Effects of a Cylindrospermopsis Raciborskii (Cyanobacteria) Strain on Mouse, Daphnia and Fish
}

\section{Pedro A. Zagatto ${ }^{1 *}$ and Aloysio da S. Ferrão-Filho}

${ }^{1}$ Laboratory Assessment and Health Promotion Environmental Institute Oswaldo Cruz-FIOCRUZ Av Brazil 4365, Manguinhos - Rio de Janeiro, RJ 21045-900, Brazil 'ZAGATTO Consultoria Ambiental e Social Ltda. R. das Garças, 81 Nova Piracicaba - Piracicaba, SP 13405-132, Brazil

\begin{abstract}
The toxicity of a cyanobacterial strain Cylindrospermopsis raciborskii was evaluated in acute toxicity tests with mouse, Daphnia and fish. The test with mouse was performed with aqueous extracts of lyophilized material. The acute tests with Daphnia were performed with three types of samples: (A) culture of cyanobacteria in ASM-1 medium; (B) concentrated cianobacterial cells in culture Daphnia medium; and (C) culture of the strain sonicated and filtered in membranes $(45 \mu \mathrm{m})$. As controls for each treatment we used ASM-1 and Daphnia culture medium and culture medium with chlorophytes as food for Daphnia sonicated and filtered in membranes $(45 \mu \mathrm{m})$, respectively. In the acute toxicity test with fish, only sample A was used. The average LD $_{50}(24 \mathrm{~h})$ in the mouse bioassays was $16.0 \pm 4.3 \mathrm{mg} \mathrm{kg}^{-1}$ and the symptoms were characteristic of neurotoxicosis. The three types of samples were toxic to Daphnia, with sample A as the most toxic and sample C the less toxic. The fish did not show any symptoms, showing greater resistance than Daphnia to this cyanobacterium. We conclude that, since this strain of $C$. raciborskii is highly toxic to mouse, when blooms of this cyanobacterium occurs in waters for public supply, special care must be taken to eliminate toxins from the water due to risks to human health. Also, since this strain is highly toxic to Daphnia, zooplankton populations may be affected in the natural environments where this cyanobacterium occurs.
\end{abstract}

Keywords: Cylindrospermopsis raciborskii; Neurotoxins; Mouse; Microcrustaceans; Daphnia; Fish

\section{Introduction}

Eutrophication process and, more recently, global warming have been considered major factors in disturbing aquatic ecosystems dynamics, leading to a shift in plankton communities and to the dominance of cyanobacteria worldwide [1]. As a consequence of cyanobacterial blooms, the impairment of water quality has lead to high costs in economy, mainly due to losses in fisheries and tourism industries [2]. More serious consequences derive from the fact that cyanobacteria may produce toxins that impose high risks to animal and human health $[3,4]$

Cyanotoxins are divided in different groups according to their mechanism of action, such as hepatotoxins, neurotoxins, dermatotoxins and cytotoxins [3]. The most studied group, the hepatotoxins, comprises the cyclic pentapeptides nodularins (NOD) and the cyclic heptapeptides microcystins (MCs). As the most diverse group, MCs have more than 90 analogues described to date $[3,5]$. MCs and NOD are potent protein phosphatases (PP1 and PP2A) inhibitors and are considered also tumor promoters [6], leading to liver failure in acute doses and dead in 45 minutes to a few hours after mice intraperitonial injection [7]. The main hepatotoxins producer genera are Microcystis, Anabaena, Nodularia and Planktothrix.

The neurotoxins are divided in groups according to their different mechanisms of action. Anatoxin-a and homanatoxin-a are alkaloids that bind irreversibly to the acetylcholine receptors and cannot be degraded by acetylcholinesterase, causing staggering, muscle twitching and gasping in mammals, and rapid death by respiratory arrest $[3,8]$. The main producing genera of anatoxins are Anabaena, Aphanizomenon, Cylindrospermopsis and Planktothrix [2]. The organophosphate compound anatoxin-a(s), on the other hand, inhibits the activity of the acetylcholinesterase, causing hypersalivation and convulsions in animals and also death by respiratory arrest $[7,8]$. The saxitoxins (STXs), also known as PST (Paralytic Shellfish Toxins), is a group comprised by about 22 variants, which can have no (saxitoxin and neosaxitoxin), only one (G-toxins) or two (C-toxins) $\mathrm{SO}_{3}$ - group in the molecule, having different toxicity for mice [9]. The mechanism of action, however, is the same for all saxitoxins, the blocking of sodium channel in the neurons, leading to impaired action potential and paralysis of muscles. Among the main PST producer genera are Anabaena, Aphanizomenon, Cylindrospermopsis, Lyngbia and Planktothrix [8]. All these neurotoxins act very fast, killing mice in a few minutes (2-30 minutes) after intraperitonial injection $[7,8]$

Cylindrospermopsis raciborskii is considered an invasive species and has been spreading quickly in the last two decades in North America and Europe [10-12] as well as in South America [13-16]. However, unlike the North American [17], Australian [18] and Thai [19] strains, which produce cylindrospermopsin $(\mathrm{CYN})$, Brazilian strains of $C$. raciborskii isolated to date produce saxitoxins [14,20,21]. Although any human deaths related to $C$. raciborskii have been documented, there have been many serious hospitalizations related to exposure to CYN [18]. Cases of intoxication and death of humans by STXs have been mostly related to consumption of marine shellfish contaminated with STXs from dinoflagellates [2]. However, any case of human intoxication involving freshwater saxitoxin-producers has been documented to date.

Monitoring programs of water bodies, regarding cyanobacterial toxins (i.e. cyanotoxins), have been implemented as mandatory requirements by the World Health Organization [22] since the episode

*Corresponding author: Pedro A. Zagatto, Laboratory Assessment and Health Promotion Environmental Institute Oswaldo Cruz-FIOCRUZ Av Brazil 4365, Manguinhos - Rio de Janeiro, RJ 21045-900, Tel: (5521) 2562-1562; Fax: (5521) 2562-1525; E-mail: aloysio@ioc.fiocruz.br

Received October 02, 2012; Accepted December 04, 2012; Published December 06,2012

Citation: Zagatto PA, Ferrão-FilhoAdS (2013)Acute Effects of a Cylindrospermopsis Raciborskii (Cyanobacteria) Strain on Mouse, Daphnia and Fish. J Ecosyst Ecogr 3: 121. doi:10.4172/2157-7625.1000121

Copyright: @ 2013 Zagatto PA, et al. This is an open-access article distributed under the terms of the Creative Commons Attribution License, which permits unrestricted use, distribution, and reproduction in any medium, provided the original author and source are credited. 
of Caruaru in 1996, in which several people died in a hemodialysis center after being treated with water from a reservoir contaminated with cyanotoxins (i.e. MCs and CYN [23]). After that, legislation and guides for human exposure to cyanotoxins, including the major routes of exposure such as oral and dermal routes through drinking water and recreational water use were established [24]. Reports of PST in several reservoirs in Brazil suggest an increasing trend of these toxins in drinking water supplies $[14,16,21]$ and indicates the urgent need for a development of detection methods that can be easily applied by environmental agencies.

The aim of this study was to test the toxic potential of a previously known PST-producer strain of Cylindrospermopsis raciborskii (T1), isolated from a farm pond in Brazil, to mouse, aquatic invertebrates (i.e. Daphnia) and vertebrates (i.e. fish).

\section{Material and Methods}

\section{Isolation and culture of the strain $\mathrm{T} 1$}

Strain T1 of the species Cylindrospermopsis raciborskii was isolated in 1993 from a farm pond in the municipality of Amparo, State of São Paulo, Brazil. The cell isolation was carried out through glass microcapillary technique. The analyses of morphological features showed that this strain is formed by solitary trichomes, generally straight or slightly curved, 100-200 $\mu \mathrm{m}$ long, slightly constricted at the cross wall, and without mucilaginous sheaths [20]. For the experiments, $6 \mathrm{~L}$ batch cultures in ASM-1 medium with moderate aeration were performed under fluorescent light at an intensity of $40 \mu \mathrm{E} \mathrm{m}^{-2} \mathrm{~s}^{-1}$, L: D cycle of $12: 12 \mathrm{~h}$ and temperature of $25 \pm 2^{\circ} \mathrm{C}$.

\section{Mouse bioassays}

These bioassays were performed with males of Swiss mice of 25 $( \pm 5) \mathrm{g}$ according to procedures described by CETESB [25]. Mice were intraperitoneally injected with different doses of a lyophilized culture of the T1 strain, previously resuspended in $0.9 \%$ saline solution and sonicated. The $\mathrm{LD}_{50}$ after $24 \mathrm{~h}$ was expressed in $\mathrm{mg} \mathrm{DW} \mathrm{kg}^{-1}$ body weight, using Trimmed Spearman-Karber statistical analysis [26]. Dead as well as control individuals have their livers extracted and weighed at the end of the bioassays for calculating the relationship liver/body weight for evaluation of hepatotoxicity.

\section{Daphnia acute toxicity tests}

Daphnia similis Claus (1876) was cultured under standardized conditions described in [27] and fed the green algae Pseudokirchneriella subcaptata (Korshikov) Hindak at a concentration of $3.5 \times 10^{6} \mathrm{cels} \mathrm{m}^{-1}$ per Daphnia day ${ }^{-1}$. For the acute tests, 20 organisms were used for each test concentration, with 5 animals per replicate placed in 4 test tubes for each one of the following treatments with cultures of T1 strain in exponential growth phase:

A) A culture of C. raciborskii with a density of $2.85 \times 10^{5}$ filaments $\mathrm{ml}^{-1}$ was diluted in ASM-1 medium to obtain each test concentration. As a control we used fresh ASM-1 medium;

B) A culture of C. raciborskii was centrifuged and the filaments were resuspended in Daphnia culture medium. As controls, pure Daphnia medium and the supernatant of the cyanobacterial culture filtered through AP20 $(45 \mu \mathrm{m})$ membranes were used with the aim to verify if the culture was releasing toxins to the medium;

C) A culture of C. raciborskii was sonicated for 10 minutes for cell lyses and liberation of toxins to the ASM-1 medium. As a control, a culture of the green algae and a culture of T1 strain, both sonicated and filtered through AP20 $(45 \mu \mathrm{m})$ membrane, were used as controls to infer about interference of cell debris.

The data of all experiments were used to build concentrationresponse curves correlating the percentage of effect (immobilization) to the filament densities. Trimmed Spearman-Karber analysis was used for the calculation of Effective Concentration $\left(\mathrm{EC}_{50}\right)$ after 48 hours.

\section{Fish acute toxicity tests}

Two fish species were utilized in these tests, Cheirodon notomelas (native) and Oreochromis niloticus (exotic). Both fish were maintained in the lab at standardized conditions as described in ABNT [28]. The tests were performed in ASM-1 medium, as described in Table 1, with cyanobacterial cultures at exponential growth phase. Treatments with aeration and without aeration were carried out for both fish. Controls consisted of fishes exposed to ASM-1 medium, with and without aeration. Measures of $\mathrm{pH}$, dissolved oxygen (D.O), conductivity and temperature were taken daily. At the end of the tests (four days) the number of active swimming fish was counted.

\section{Results}

\section{Mouse bioassays}

The mean value of $\mathrm{LD}_{50}( \pm \mathrm{SD})$ for three trials of the mouse bioassays was $16.0( \pm 4.3) \mathrm{mg} \mathrm{DW} \mathrm{kg}^{-1}$ body weight and the results for each test and $95 \%$ confidence interval are presented in Table 2 . The symptoms were typical of neurotoxins, such as ataxia, convulsions and paralysis, with respiratory arrest and dead after 1-5 minutes. The liver/ body weight ratio of mice did not show any sign of increase relative to control, staying bellow the critical range of $8-10 \%$ considered for hepatotoxicity [7].

\begin{tabular}{|l|c|c|}
\hline \multirow{2}{*}{ Test conditions } & \multicolumn{2}{|c|}{ Fish species } \\
\cline { 2 - 3 } Number of cell filaments $\mathrm{mL}^{-1}$ & C. notomelas & O. niloticus \\
\hline Volume of test solution $(\mathrm{L})$ & $2.0 \times 10^{5}$ & $1,9 \times 10^{5}$ \\
\hline Temperature $\left({ }^{\circ} \mathrm{C}\right)$ & 2 & 2 \\
\hline Photoperiod (light/dark) & $23 \pm 2$ & $23 \pm 2$ \\
\hline Duration of the test (hours) & $12 / 12 \mathrm{~h}$ & $12 / 12 \mathrm{~h}$ \\
\hline Number of fish/treatment & 96 & 56 \\
\hline Mean fish weight $(\mathrm{g})$ & 10 & $16.2 \pm 5.4$ \\
\hline Mean fish length $(\mathrm{cm})$ & $7.4 \pm 0.15$ & $9.9 \pm 1.2$ \\
\hline
\end{tabular}

Table 1: Environmental conditions during the tests with fish.

\begin{tabular}{|c|c|c|}
\hline Test number & $\mathrm{LD}_{50}\left(\mathrm{mg} \mathrm{kg}^{-1}\right)$ & $95 \%$ Confidence interval $\left(\mathrm{mg} \mathrm{kg}^{-1}\right)$ \\
\hline 1 & 15.2 & $8.1-28.5$ \\
\hline 2 & 12.1 & $7.8-18.7$ \\
\hline 3 & 20.7 & $13.3-32.0$ \\
\hline Mean \pm SD & $16.0 \pm 4.3$ & --- \\
\hline
\end{tabular}

Table 2: Results of the mouse bioassays with aqueous extracts of $\mathrm{T} 1$ strain.

\begin{tabular}{|l|c|c|}
\hline Treatment & $\begin{array}{c}\mathrm{EC}_{50} \\
\text { (filaments } \mathrm{mL}^{-1} \text { ) }\end{array}$ & $\begin{array}{c}95 \% \text { Confidence interval } \\
\text { (filaments } \mathrm{mL}^{-1} \text { ) }\end{array}$ \\
\hline A. Culture of C. raciborskii in ASM-1 & 24.4 & $16.1-36.9$ \\
\hline B. Cell concentrate in Daphnia medium & 74.5 & $53.5-103.9$ \\
\hline C. Cell sonicated & 3605 & $2332-5572$ \\
\hline
\end{tabular}

Table 3: Results of the acute toxicity tests with Daphnia. 


\section{Daphnia acute toxicity tests}

The results showed that the strain T1 caused acute toxic effects in all treatments (Table 3). In the treatments with the culture in ASM1 medium and resuspended in Daphnia medium, about only 24-75 filaments $\mathrm{ml}^{-1}$ are sufficient to cause immobilization of $50 \%$ of the organisms, while the sonicated culture showed lower toxicity $\left(\mathrm{EC}_{50} \cong\right.$ 3600 filaments $\mathrm{ml}^{-1}$ ) to Daphnia. The controls of each experimental treatment did not presented any toxic effect on Daphnia.

\section{Fish acute toxicity tests}

The results suggested that the strain $\mathrm{T} 1$ was not toxic to both fish species. There was no mortality in the cyanobacterial treatments with aeration, in which dissolved oxygen (D.O) stayed above $5.0 \mathrm{mg} \mathrm{l}^{-1}$. By the other hand, in the treatments without aeration a high mortality rate was observed in O. niloticus (Figure 1A) and a lower mortality rate in C. notomelas (Figure 1B), besides a high control mortality (60\%) and low levels of D.O. $\left(<3.0 \mathrm{mg} \mathrm{l}^{-1}\right)$. Therefore, the mortality of fishes in experiments without aeration may be due to low dissolved oxygen in the water. All other physical-chemical parameters stayed between acceptable levels.

\section{Discussion}

Mouse bioassays revealed that the strain T1 is highly toxic to mice. In the mouse bioassays, animals showed symptoms typical of neurotoxicity, such as trembling, ataxia, convulsions and paralysis, and dead by respiratory arrest after 1-5 minutes. Animals, however, did not show an increase in liver/body weight ratio, indicating no sign of hepatotoxicity. Also, this strain has been characterized as a PSTproducer by LAGOS [20], producing STX and NeoSTX, and its toxicity was calculated as $3.3 \mathrm{MU} / \mathrm{mg}$ of lyophilized sample. Although we have not analyzed the toxin content of the strain T1 culture, the symptoms and rapid death of mice are typical of neurotoxicity.

This strain proved to be very toxic also to Daphnia, showing high toxicity when administered either as intact filaments or in extracts of lysed cells (sonicated). However, toxicity was extremely higher when cultures were administered as intact cells (i.e. $\mathrm{EC}_{50}-48 \mathrm{~h}=25-75$ filaments $\mathrm{ml}^{-1}$ ) compared as to sonicated cultures (i.e. $\mathrm{EC}_{50}-48 \mathrm{~h}=3600$ filaments $\mathrm{ml}^{-1}$ ). On the other hand, the filtrate of the culture was not toxic to Daphnia, suggesting that toxins were not released to the medium during cell growth. Also, pure, freshly prepared ASM-1 medium did not cause any effect to Daphnia, showing no influence of cyanobacterial medium on the results. When compared in terms of cell density, however, the results with cell extracts do not agree with the results with intact filaments. As these toxins are, in general, considered endotoxins, any presence of toxins in filtrate should not be expected. However, during the sonication procedure, cell lyses occur, releasing the toxins to the medium. Thus, the disagreement between cell extracts and intact cell cultures, which were more toxic than cell extracts, cannot be accounted only by cell lyses during the filtration process by Daphnia, since extracts are supposed to have much more released toxins to the medium in direct contact with animals. However, the uptake of toxins by the digestive tract can be much higher than the uptake from the surrounding medium, considering that there is no active transports of these toxins across cells of the gills and that zooplankton have a chitinous carapace. ROHRLACK [29] described the mechanism of intoxication by MCs in Daphnia as being primarily a digestive uptake. After digestion of cells in the midgut, where toxins accumulate, MCs are transported directly into the blood through the gut epithelium.

HANEY [30] tested the effects of filtrates of a culture of PSTproducer Aphanizomenon floes-aquae in D. carinata and found that these samples caused a reduction in the thoracic appendage beating rate and an increase in rejection rate of particles by the postabdomen, indicating that this cyanobacterium was actively excreting some toxic compound to the medium. Their results with pure STX supported the hypothesis that these toxins were responsible for the effects observed and that they may act as chemical cues for the detection of toxic strains in the water, leading to a behavioral change in the filtration process of the animals, as a tentative to decrease ingestion rates of toxic cyanobacteria. Our results with filtrate samples, however, demonstrates that $C$. raciborskii do not release significant amounts of toxins to the medium, since animals survived well in these treatments. Nevertheless, intracellular toxins caused immobilization of the daphniids, which is consistent with a neurotoxic effect.

An alternative explanation for the higher mortality in the treatments with intact cell cultures is that filaments can interfere with the Daphnia filtration process $[31,32]$. However, as the treatments with sonicated and filtered cultures of C. raciborskii caused toxic effect on Daphnia, filaments only cannot account for the negative effects.

Other studies have showed toxic effects of C. racibosrkii strains to Daphnia. Nogueira et al. [33] studied the effects of a CYN-producer
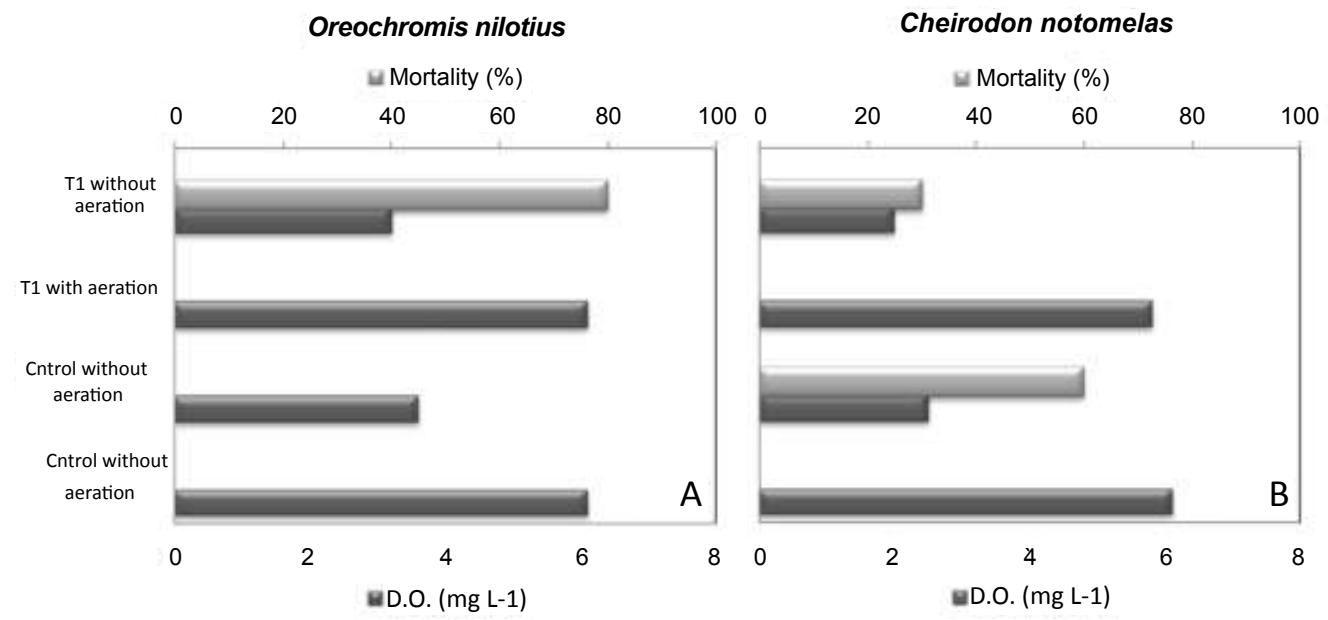

Figure 1: Results of the acute toxicity tests with fish exposed to C. raciborskii in ASM-1 medium. Mortality (\%) and Dissolved Oxygen (D.O.) in mg L ${ }^{-1}$. a 
strain (Cylin-A) and to a non CYN-producer strain (Cylin-P) of C. racibosrkii to $D$. magna and the results showed that both strains reduced the survivorship and growth of the cladoceran, with the Cylin-A being more effective. In another study, Nogueira et al. [34] showed the accumulation of STXs in D. magna exposed to a strain of $A$. issatschenkoi and showed that this cyanobacterium affected the fitness and growth potential of this cladoceran. Ferrão-Filho et al. [21] showed that another PST-producer strain of C. raciborskii (T3), isolated from Billings Reservoir in the State of São Paulo, was toxic to D. pulex and to Moina micrura, causing a reversible paralysis of the swimming movements of these animals with cell concentrations as low as $10^{2}$ to $10^{3}$ cells $\mathrm{ml}^{-1}$, respectively. In another study, Ferrão-Filho et al. [35] used a $C$. raciborskii strain (CYRF-01) isolated from Funil Reservoir in the State of Rio de Janeiro, as well as natural samples from this reservoir, showing that paralysis may occur in less than one hour and its is correlated with the cell biomass and STXs content of the cells.

In this study, fish was not affected by the presence of toxic cells in the water. The mortality observed in the treatments without aeration may have resulted from an artifact caused by oxygen depletion. In experiments with zebra fish (Danio rerio), Ferrão-Filho et al. [36] showed that the swimming behavior of this fish was altered, showing hyperactivity (i.e. higher mean velocity) during 5 hours exposure to the strain CYRF-01 (C. raciborskii), and considered that this effect may be caused by compounds other than STXs. In the same study, however, $D$. pulex had a decrease in its activity with this strain in two hour exposure, which is compatible with the mechanism of action of STXs. In acute tests with strain CYRF-01 (non-published data), D. rerio was not sensitive to concentrations as high as $5 \times 10^{5}$ cells $\mathrm{ml}^{-1}$ of intact cells and to $100 \mathrm{mg} \mathrm{l}^{-1}$ of lyophilized cell extracts. Zagatto et al. [37], on the other hand, showed that $D$. rerio fish larvae were senstitive to two other STXs-producer strains of $C$. racibosrskii in chronic exposures (7 days). Therefore, these data show that fish larvae seem to be more sensitive to toxins produced by C. raciborskii than adult fish.

Also, the discrepancy between results of Daphnia tests and fish tests show that these organisms do not have the same susceptibility to neurotoxins or may differ in the exposure route. While Daphnia main exposure route seems to be the digestive tract, by ingestion of the cells [29], fish might by exposed mainly through gills, absorbing toxins directly from the water. However, the absorption of toxins by gills and epidermis in aquatic vertebrates is considered low [38-41]. In natural systems, the concentration of dissolved toxins is relatively low, up to $0.02 \mathrm{mg} \mathrm{L}^{-1}$ [42]. This is mainly due to the fact that cyanotoxins are endotoxins, released out of the cells only during the senescence of the bloom [43]. Therefore, it is likely that aquatic organisms are exposed to low levels of dissolved toxins in the natural environment. Besides that, the uptake of dissolved toxins directly from the water do not represent the typical and ecologically relevant exposure route of aquatic organisms, that is via food web [44].

\section{Conclusions and Considerations}

The results of this study showed that $C$. raciborskii is highly toxic to mice, which showed symptoms of neurotoxicosis. Therefore, when blooms of this cyanobacterium occurs in drinking waters supplies, special care must be taken to eliminate toxins from the water due to risks to human health.

Also, strain T1 is highly toxic to Daphnia, which were paralyzed in the acute tests with a few filaments of $C$. racibosrkii. Thus, in case of blooms of STXs-producer strains of this cyanobacterium, populations of more sensitive organisms such as Daphnia may be affected in the natural environment, leading to a shift in the composition of zooplankton community.

Adult fish, by the other hand, seems to be not affected by the toxins or filaments of $C$. raciborskii, at least in short term exposure.

Another consideration to be made is in regard to the use of mice as test organisms in cases of algal blooms in drinking water supply. Since issues of bioethics has lead an increasing consensus among the scientific community in eliminating the use of mammals in standard toxicity testing, a promising alternative in the detection of the presence of toxic filaments C. raciborskii is the use of the aquatic organism such as Daphnia, since this organism proved to be very sensitive to STXsproducer strains of this cyanobacterium [45].

Finally, the presence of toxic strains of cyanobacteria, such as neurotoxic C. raciboirskii, in drinking water supply reservoirs shows that public health may be threatened. Therefore, some effort must be made by the government environmental agencies to monitor blooms of cyanobacteria and the presence of their toxins in the water.

\section{Acknowledgements}

We would like to thank Maria do Carmo Carvalho for the identification of the strain T1 and Márcia A. Aragão by the conduction of the toxicity tests, both from CETESB-SP.

\section{References}

1. Paerl HW, Huisman J (2008) Blooms like it hot. Science 320: 57-58

2. Landsberg JH, Saxitoxins (2002) In: Stickney, RR (Ed.) The effects of harmful algal blooms on aquatic organisms. Reviews in Fisheries Sciences 10: 113390

3. Chorus I, Bartram J (1999) Toxic cyanobacteria in water: A Guide to their public health consequences, monitoring and management. E and FN Spon, London, on behalf of the World Health Organization, Geneva. 400.

4. Stewart I, Seawright AA (2008) Cyanobacterial Poisoning in Livestock, wild mammals and Birds-An Overview. In: Hudnell HK (Ed.) Cyanobacterial Harmfu Algal Blooms: State of the Science and Research Needs. New York, USA Springer Science. Advances in Experimental Medicine and Biology 619: 613-637.

5. Spoof L (2005) Microcystins and Nodularins. In: Meriluoto, J, Codd GA (Eds.) Toxic cyanobacterial monitoring and cyanotoxin analysis. Finland, Pargas: Åbo Akademi University Press 65: 149.

6. Falconer IR (1991) Tumor promotion and liver injury caused by oral consumption of Cyanobacteria. Environmental Toxicology and Water Quality 6: 177-184.

7. Sivonen K (1996) Cyanobacterial toxins and toxin production. Phycologia 35 $12-24$

8. Codd GA, Bell SG, Kaya K, Ward CJ, Beattie KA, et al. (1999) Cyanobacteria toxins, exposure routes and human health. European Journal of Phycology 34 405-415.

9. Shimizu Y (1987) Dinoflagellate Toxins. In: Taylor JFR (Ed.) Biology of Dinoflagellates. Blackwell Scientific, 282-315.

10. Chapman A, Schelske C (1997) Recent appearance of cylindrospermopsis (Cyanobacteria) In Five Hypereutrophic Florida Lakes. 33: 1091-1000.

11. Gugger M, Molica R, Le Berre B,Dufour P, Bernard C, et al. (2005) Genetic diversity of Cylindrospermopsis Strains (Cyanobacteria) Isolated from four continents. Applied Environmental Microbiology 71: 1097-1100.

12. Conroy JD, Quinlan EL, Kane DD, Culver DA (2007) Cylindrospermopsis In Lake Erie: Testing Its Association with other Cyanobacterial Genera and Major Limnological Parameters. Journal of Great Lakes Research 33: 519-535.

13. Huszar VLM, Silva LHS, Marinho MM, Domingos P, Sant Anna C (2000) Cyanoprokaryote Assemblages in Eight Productive Tropical Brazilian Waters. Hydrobiologia 424: 67-77.

14. Molica RJR, Olivera EJA, Carvalho PVVC, Costa ANSF, Cunha MCC, et al. (2002) Toxins In The Freshwater Cyanobacterium Cylindrospermospsis Raciborskii (Cyanophyceae) isolated from tabocas reservoir in caruaru, brazil, Including demonstration of a new saxitoxin analogue. Phycology 41: 606-611. 
Citation: Zagatto PA, Ferrão-Filho AdS (2013) Acute Effects of a Cylindrospermopsis Raciborskii (Cyanobacteria) Strain on Mouse, Daphnia and Fish. J Ecosyst Ecogr 3: 121. doi:10.4172/2157-7625.1000121

Page 5 of 5

15. Bouvy M, Pagano M, Troussellier M (2001) Effects of a cyanobacterial bloom (Cylindrospermopsis Raciborskii) on bacteria and zooplankton communities in ingazeira reservoir (Northeast Brazil). Aquatic Microbiological Ecology 25: $215-227$

16. Yunes JS, Cunha NT, Barros LP, Proença LAO, Monserrat JM (2003) Cyanobacterial Neurotoxins from Southern Brazilian Freshwaters. Commentaries on Toxicology 9:103-115.

17. Burns J, Chapman A, Williams C, Flewelling L. Carmichael W, et al. (2000) Cyanotoxic Blooms in Florida's (USA) Lakes, Rivers and Tidal River Estuaries: The Recent Invasion of toxigenic Cylindrospermopsis Raciborskii and Consequences For Florida's Drinking Water Supplies. IX Conference on Harmful Algal Blooms, Hobart, Tasmania, Australia.

18. Griffiths DJ, Saker ML (2003) The palm island mystery disease 20 Years on: A review of research on the Cyanotoxin Cylindrospermopsin. Environmental Toxicology 18: 78-93.

19. Li R, Carmichael WW, Brittain S, Eaglesham GK, Shaw GR, et al. (2001) Isolation and identification of the Cyanotoxin Cylindrospermopsin and DeoxyCylindrospermopsin from a thailand strain of cylindrospermopsis raciborskii (Cyanobacteria). Toxicon 39: 973-980

20. Lagos N, Onodera H, Zagatto PA, Andrionolo D, Azevedo SMFO, et al. (1999) The first evidence of paralytic shellfish toxins in the freshwater cyanobacterium cylindrospermopsis raciborskii isolated from brasil. Toxicon 37: 1359-1373.

21. Ferrão-Filho AS, Costa SM, Ribeiro MGL, Azevedo SMFO (2008) Effects of a saxitoxin-producer strain of cylindrospermopsis Raciborskii (Cyanobacteria) on the swimming movements of cladocerans. Environmental Toxicology 23: 161-168.

22. WHO (2003) Cyanobacterial toxins: Microcystin-LR in drinking-water Background document for Preparation of WHO Guidelines for drinking-water quality, Geneva, World Health Organization.

23. Carmichael WW, Azevedo SMFO, Na JS, Molica RJR, Jochimsen EM, et al. (2001) Human fatalities from Cyanobacteria: chemical and biological evidence for cyanotoxins. Environmental Health Perspectives 10: 663-668.

24. Burch MD Effective Doses, Guidelines \& Regulations. (2008) In: Hudnell HK (Ed.) Cyanobacterial Harmful Algal Blooms: State of the Science and Research Needs. New York, USA: Springer Science. Advances in Experimental Medicine and Biology 619: 831-853.

25. CETESB, São Paulo (1993) Água-Teste Para Avaliação Da Toxicidade Aguda De Cianofíceas (Algas Azuis). São Paulo, CETESB, Norma Técnica L5 055. 12.

26. Hamilton M, Russo RC, Thurston RV (1977) Trimmed Spearman-Karber method for estimating mediam lethal concentration in toxicity bioassays. Environmental Science \& Technology 11: 714-719.

27. ABNT, Associação Brasileira De Normas Técnicas. (1993) ABNT/NBR 12713, Água-Ensaio De Toxicidade Aguda Com Daphnia Similis Claus, 1876 (Cladorcera, Crustácea). ABNT, Rio De Janeiro, 16.

28. ABNT, Associação Brasileira De Normas Técnicas, (1993) ABNT/NBR 12715 Água-Ensaio De Toxicidade Aguda Com Peixes. Parte II. Sistema SemiEstático. ABNT, Rio De Janeiro, 15.

29. Rohrlack T, Christoffersen K, Dittman E, Nogueira I, Vasconcelos V, et al. (2005) Ingestion of microcystins by daphnia: Intestinal uptake and toxic effects. Limnology and Oceanography 50: 440-448.

30. Haney JF, Sasner JJ, Ikawa M (1995) Effects of products released by Aphanizomenon Flos-Aquae and purified saxitoxin on the movements of daphnia carinata feeding appendages. Limnology and Oceanography 40: 263272

31. Gliwicz ZM, Lampert W (1990) Food thresholds in daphnia species in the absence and presence of Blue-Green Filaments. Ecology 71: 691-702.

32. Demott WR, Moxter F (1991) Foraging Cyanobacteria by Copepods: responses to chemical defenses and Resource Abundance. Ecology 72: 1820-1834.

Citation: Zagatto PA Ferrão-Filho AdS (2013) Acute Effects of a Cylindrospermopsis Raciborskii (Cyanobacteria) Strain on Mouse, Daphnia and Fish. J Ecosyst Ecogr 3: 121. doi:10.4172/2157-7625.1000121
33. Nogueira ICG, Pereira P, Dias E, Pflugmacher S, Wiegand, et al. (2004) Accumulation of Paralytic Shellfish toxins (PST) from the Cyanobacterium Aphanizomenon Issatschenkoi by cladoceran daphnia magna. Toxicon 44 773-780.

34. Nogueira ICG, Saker ML, Pflugmacher S, Wiegand C, Vasconcelos VM (2004) Toxicity of the Cyanobacterium Cylindrospermopsis Raciborskii to aaphnia magna. Environmental Toxicology 19: 453-459.

35. Ferrão-Filho AS, Soares MCS, Magalhães VF, Azevedo SMFO (2010) A rapid bioassay for detecting saxitoxins using a daphnia acute toxicity test. Environmental Pollution 158 : 2084-2093.

36. Ferrão-Filho AS, Cunha R, Magalhães VF, Soares MCS, Baptista DF (2007) Evaluation of Sub-Lethal Toxicity of Cyanobacteria on the swimming activity of Aquatic organisms by image analysis. Journal of Brazilian Society of Ecotoxicology 2: 1-8

37. Zagatt PA, Buratini SA, Aragão M, Ferrão-Filho AS (2012) Neurotoxicity of two Cylindrospermopsis Raciborskii Strains to mice, daphnia and fish Environmental Toxicology and Chemistry 31: 857-862.

38. Tencalla FG, Dietrich DR, Schlatter C (1994) Toxicity of microcystis aeruginosa peptide toxin to yearling Rainbow Trout (Oncorhyncus Myskiss). Aquatic Toxicology 30: 215-224.

39. Fisher WJ, Dietrich DR (2000) Toxicity of the Cyanobacterial Cyclic Heptapepitide Toxins Microcystin-LR And -RR in early stages of the African Clawed Frog (Xenopus Laevis). Aquatic Toxicology 49: 189-198.

40. Osswald T, Carvalho AP, Claro J, Vasconcelos V (2008) Effects of Cyanobacteria extracts containing Anatoxin-A and of Pure Anatoxin-A on early developmental stages of carp. Ecotoxicol Environ Saf 72: 473-478.

41. Berry JP, Gibb PDL, Schmale MC, Saker ML (2009) Toxicity of Cylindrospermopsin, and other apparent metabolites from Cylindrospermopsis Raciborskii and Aphanizomenon Ovalisporum, to the zebrafish (Danio Rerio) Embryo. Toxicon 53: 289-299.

42. Christoffersen K (1996) Ecological Implications of Cyanobacterial Toxins in aquatic food webs. Phycologia 35: 42-50.

43. Zurawell R, Chen H, Burke JM, Prepas EE (2005) Hepatotoxic Cyanobacteria: A review of the biological importance of microcystins in freshwater environments. Journal of Toxicology and Environmental Health, Part B 8: 1-37.

44. Wilson AE, Sarnelle O, Tillmanns AR (2006) Effects of Cyanobacterial Toxicity and Morphology on the population growth of freshwater zooplâncton: MetaAnalyses of laboratory experiments. Limnology and Oceanography 51: 1915 1924.

45. Ferrão-Filho AS, Soare MCS, Magalhães VF, Azevedo SMFO (2010) A rapid bioassay for detecting Saxitoxins Using A Daphnia Acute Toxicity Test. Environmental Pollution 158: 2084-2093.

\section{Submit your next manuscript and get advantages of OMICS Group submissions}

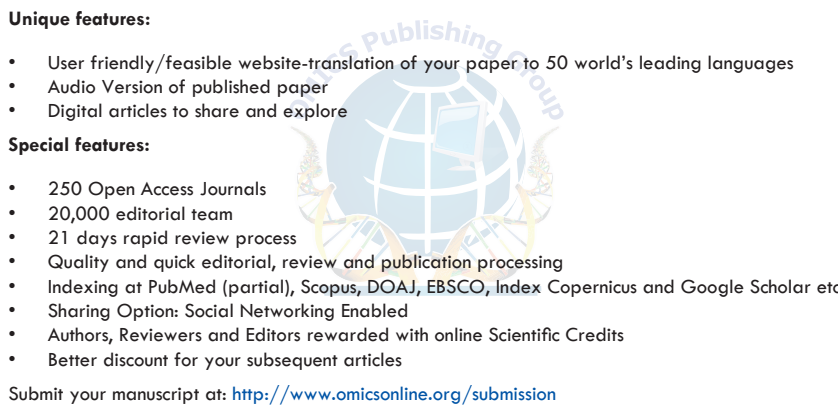

